\title{
Screening of Fusarium graminearum Isolates for Enzymes Extracellular and Deoxynivalenol Production
}

\author{
Leonel M. Ortega, Gisele E. Kikot, Andrea L. Astoreca, and Teresa M. Alconada \\ Research and Development Center for Industrial Fermentations (CINDEFI), UNLP, CCT-La Plata, CONICET, School of Science, \\ La Plata National University, B1900ASH La Plata, Argentina
}

Correspondence should be addressed to Teresa M. Alconada; alconada@biotec.org.ar

Received 30 May 2013; Revised 20 September 2013; Accepted 10 October 2013

Academic Editor: Maria João Sousa

Copyright (c) 2013 Leonel M. Ortega et al. This is an open access article distributed under the Creative Commons Attribution License, which permits unrestricted use, distribution, and reproduction in any medium, provided the original work is properly cited.

\begin{abstract}
Fusarium graminearum, the main etiological agent of Fusarium head bligh, has high intraspecific genetic diversity, which is related to the variability in the aggressiveness among isolates against wheat. The aggressiveness involves different mechanisms as the production and liberation of extracellular enzymes and mycotoxins. In the present paper, several F. graminearum isolates obtained from wheat spikes from Pampas region, Argentina, were screened for polygalacturonase (pectinase), proteolytic, and lipase extracellular enzymatic activities production, as well as for the capacity to produce deoxynivalenol. The enzymatic production in terms of magnitude was varied among isolates, which could be related to a differential capacity to infect wheat. Both polygalacturonase as proteolytic activities had a maximum activity in the first days of incubation. Instead, the lipase activity reached its maximum activity after advanced incubation time. Deoxynivalenol production was delayed over time with respect to the first enzymatic activities, which would infer its relation to the progress of the disease in the host, more than with the early stages of infection. The characterization carried out in this research would allow us to apply a selection criterion among isolates for further research.
\end{abstract}

\section{Introduction}

Fusarium head blight (FHB) is one of the most devastating diseases of small-grain cereals. Severe epidemics have occurred all over the world, affecting wheat in all cropping areas around the world, including those in Argentina, altering the yield and quality of grains, as manifest in their weight, carbohydrate and protein composition, and the mycotoxins presence such as deoxynivalenol (DON) [1-3]. Fusarium graminearum is the main etiologic agent of this disease in South America. The aggressiveness of F. graminearum involves different mechanisms or components, as the production and release of extracellular enzymes that degrade the cell wall (CWDEs) which are crucial in the processes of colonization and establishment of the disease [4-6]. Therefore, a reduced secretion of enzymes might retard both the fungal growth on the host surface and the infective process, thus giving the host more time to muster a defensive response [7-9]. Once the infection is established, mycotoxins are released and they interfere with the metabolism, physiologic processes and structural integrity of the host cell [10]. The CWDEs participation in the infection process, by Fusarium spp. has been analyzed through diverse methodologies, which include cytological, ultrastructural, immunological, and molecular DNA studies; the results obtained suggest that these enzymes might be important phytopathogenicity factors during infection of wheat spikes [11-13].

Phalip et al. [14] analyzed the diversity of $F$. graminearum exoproteome grown on plant cell wall and identified proteins belonging to 24 different enzyme classes involved in the digestion of the complete plant cell wall. Although, F. graminearum produced diverse CWDE such as cellulases, xylanases, and pectinases during the infection in wheat spikes, the pectic enzymes are the first polysaccharidases to be induced when fungi are cultured on isolated plant cell walls and the first to be produced in infected tissue. These enzymes soften the cell walls, increasing accessibility of cell wall components for degradation by other enzymes, enabling the success of further infection steps and the spread of the mycelium into the inner tissues of the plant $[4,15-18]$. Due to the crucial role of pectic enzymes, as the polygalacturonase activity, in the process 
of colonization, they are often required for full virulence [15].

Another group of relevant enzymes in phytopathogenic process are those catalyzing proteolysis, referred to as proteases or proteolytic activities. Together with the CWDEs, the proteases act at an early stage of infection to degrade the structural proteins of the cell walls in order to invade the host. At a later stage these enzymes are responsible for the degradation of the grain's storage proteins, altering the quality parameters of raw material [19-21].

Although the role of lipases in the infection process by F. graminearum in wheat has been scarcely reported, it suggested their importance in the penetration of fungal hyphae in the host $[9,22]$. On observation of the subcuticular growth of F. graminearum after host penetration, Pritsch et al. [23] suggested that lipases might have participated to a certain extent in the prior degradation of the cuticle.

Regarding the mycotoxins, it is considered that they may have a more consequential influence on the progress of infections on cereal plants than as phytopathogenicity factors determining the capability of infection $[24,25]$. The main mycotoxin produced by F. graminearum is the DON and its precursors. In some instances, a strong association has been found between the severity of the FHB and DON concentration in infected grains [26].

The high genetic diversity present in F. graminearum would be related to the variability in aggressiveness among isolates towards the host and thus with their capacity to produce enzymes and mycotoxins. Therefore, the characterization conducted in this research is useful, since it allows applying a selection criterion among isolates for further investigation.

\section{Material and Methods}

2.1. Biological Material. Eleven F. graminearum isolates were obtained from wheat spikes from different sites of Pampas region, Argentina (named as numbers 1 to 11). The monosporic isolates were kept in tubes with $2 \%$ synthetic nutrient agar (SNA: $0.1 \% \mathrm{KH}_{2} \mathrm{PO}_{4}, 0.1 \% \mathrm{KNO}_{3}, 0.05 \% \mathrm{MgSO}_{4} \cdot 7 \mathrm{H}_{2} \mathrm{O}$, $0.05 \% \mathrm{KCl}, 0.02 \%$ glucose, $0.02 \%$ sucrose, and $2 \%$ agar) under a layer of mineral oil at $4^{\circ} \mathrm{C}$.

\subsection{Enzymatic Analysis}

\subsubsection{Polygalacturonase Activity}

Culture Conditions. The isolates were cultivated for 15 days in a modified Czapek-Dox medium $\left(0.2 \% \mathrm{C}_{4} \mathrm{Hl}_{2} \mathrm{~N}_{2} \mathrm{O}_{6}, 0.1 \%\right.$ $\mathrm{KH}_{2} \mathrm{PO}_{4}, 0.05 \% \mathrm{MgSO}_{4} \cdot 7 \mathrm{H}_{2} \mathrm{O}, 0.05 \% \mathrm{KCl}, 0.25 \%$ glucose, $0.125 \%$ citrus pectin and $0.125 \%$ commercial oat bran as carbon sources and/or enzyme inducers, $0.1 \%$ yeast extract, and $0.1 \mathrm{~mL}$ traces elements; containing $1 \mathrm{~mL}$ of this solution: $100 \mathrm{mg} \mathrm{Na} \mathrm{B}_{4} \mathrm{O}_{7} \cdot 10 \mathrm{H}_{2} \mathrm{O}, 70 \mathrm{mg} \mathrm{ZnSO}_{4} \cdot 7 \mathrm{H}_{2} \mathrm{O}, 50 \mathrm{mg}$ $\mathrm{FeSO}_{4} \cdot 7 \mathrm{H}_{2} \mathrm{O}, 10 \mathrm{mg} \mathrm{CuSO}_{4} \cdot 5 \mathrm{H}_{2} \mathrm{O}, 10 \mathrm{mg} \mathrm{MnSO}_{4} \cdot 4 \mathrm{H}_{2} \mathrm{O}$, $\left.10 \mathrm{mg}\left(\mathrm{NH}_{4}\right)_{6} \mathrm{Mo}_{7} \mathrm{O}_{24} \cdot 4 \mathrm{H}_{2} \mathrm{O}\right)$ [27] at $28^{\circ} \mathrm{C}$ in darkness, under shaking $(150 \mathrm{rpm})$ in $125 \mathrm{~mL}$ Erlenmeyer flasks containing $25 \mathrm{~mL}$ of medium. The inoculum was prepared from $5 \mathrm{~mm}$ plugs cut out from the margin of a 5-day-old colony growing on Petri dishes containing $2 \%$ potato agar at $26^{\circ} \mathrm{C}$. The whole content of each Erlenmeyer was withdrawn periodically for 15 days. The supernatant was separated from the mycelium by centrifugation at $7,650 \times \mathrm{g}$ for $30 \mathrm{~min}$ and stored at $-20^{\circ} \mathrm{C}$ until dosage.

Polygalacturonase Activity Assay. Polygalacturonase (PG) activity was determined at $40^{\circ} \mathrm{C}$ by using $450 \mu \mathrm{L}$ of $0.1 \%$ polygalacturonic acid as substrate with $50 \mathrm{mM}$ acetate buffer, $\mathrm{pH} 5.0$, and $50 \mu \mathrm{L}$ of enzymatic extract. The enzymatic activity was determined by measuring the liberation of reducing groups by Somogyi method [28]. Each measure was determined after subtracting two blanks, one without substrate and the other one without enzymatic extract. One enzymatic unit was defined as the amount of necessary enzyme to release $1 \mu \mathrm{mol}$ of uronic acid per minute under the above mentioned reaction conditions. Protein content was determined by the Bradford method [29].

\subsubsection{Proteolytic Activity}

Culture Conditions. The inoculum was prepared from $5 \mathrm{~mm}$ plugs cut out from the margin of a 5-day-old colony growing on Petri dishes containing $2 \%$ potato agar at $26^{\circ} \mathrm{C}$. Preculture was performed in complete medium and incubated for $24 \mathrm{~h}$ under shaking $(150 \mathrm{rpm})$ at $28^{\circ} \mathrm{C}$ and darkness. The preculture was inoculated into Erlenmeyer flasks of $500 \mathrm{~mL}$ with $200 \mathrm{~mL}$ of protease inducer medium according to Hellweg [30], with the addition of vital gluten as an inducer. Incubation was carried out under shaking $(150 \mathrm{rpm})$ at $28^{\circ} \mathrm{C}$ and darkness. Samples were taken periodically for 15 days. The supernatant was stored at $-20^{\circ} \mathrm{C}$ until dosage.

Proteolytic Activity Assay. Assays were performed on casein. The reaction mixture contained $1.1 \mathrm{~mL}$ of $1 \%$ casein solution and $0.1 \mathrm{~mL}$ of enzyme solution, both in $0.1 \mathrm{M}$ Tris- $\mathrm{HCl}$ buffer ( $\mathrm{pH}$ 8.0) containing $10 \mathrm{mM}$ cysteine. The reaction was carried out at $37^{\circ} \mathrm{C}$ and stopped by the addition of $5 \%$ trichloroacetic acid $(1.8 \mathrm{~mL})$; then each test tube was centrifuged at $4000 \times \mathrm{g}$ for $20 \mathrm{~min}$ and the absorbance of the supernatant was read at $280 \mathrm{~nm}$. Each measure was determined after subtracting two blanks, one without substrate and the other one without enzymatic extract. An arbitrary enzyme unit ("caseinolytic unit," Ucas) was defined as the amount of enzyme that produces an increase of one absorbance unit ( $1 \mathrm{~cm}$ light-path) per minute in the assay conditions [31].

\subsubsection{Lipase Activity}

Culture Conditions. Cultures were performed in $1000 \mathrm{~mL}$ Erlenmeyers with $200 \mathrm{~mL}$ culture medium containing $50 \mathrm{mM}$ phosphate buffer, $\mathrm{pH} 7.0,1 \%$ yeast extract, $1 \%$ tryptone, and $1 \%$ olive oil emulsion (10\% olive oil and $1 \%$ Tween 80 emulsified in blender for $3 \mathrm{~min}$ ). The inoculum was prepared from $5 \mathrm{~mm}$ plugs cut out from the margin of a 5-day-old colony growing on Petri dishes containing $2 \%$ potato agar at $26^{\circ} \mathrm{C}$. Incubation was carried out under shaking (150 rpm) at $28^{\circ} \mathrm{C}$ and darkness. Samples were taken periodically for 15 days. The supernatant was stored at $-20^{\circ} \mathrm{C}$ until dosage.

Lipase Activity Assay. Lipase hydrolytic activity was measured spectrophotometrically at $440 \mathrm{~nm}$ with p-nitrophenyl 
palmitate (p-NPP, $1 \mathrm{mM}$ in acetone) as substrate at $37^{\circ} \mathrm{C}$ in $50 \mathrm{mM}$ Tris- $\mathrm{HCl}$ buffer ( $\mathrm{pH}$ 7.0). Each measure was determined after subtracting two blanks, one without substrate and the other one without enzymatic extract. One unit of enzyme activity was defined as the amount of enzyme that releases $1 \mu \mathrm{mol}$ of $\mathrm{p}$-NPP per minute under the above mentioned reaction conditions.

\subsection{Determination of Deoxynivalenol}

2.3.1. Gamma Sterilization of Wheat Grains and Adjustment of the Water Activity. Wheat grains were irradiated with 10-12 KGrays of gamma irradiation to retain the grain germinative ability. The grains were checked for sterility and absence of deoxynivalenol (DON) and stored aseptically at $4^{\circ} \mathrm{C}$. Flasks were subsequently refrigerated at $4^{\circ} \mathrm{C}$ for $48 \mathrm{~h}$ with periodic manual agitation to allow absorption and equilibrium. Finally, $a_{W}$ levels were confirmed by using an Aqualab Series 3 (Labcell Ltd., Basingstoke, Hants, UK) and the corresponding absorption curve for each item was performed. Initial $a_{W}$ grains were also measured and then rehydrated, according to the curve to get the desired $a_{W}$ (0.995), which is the optimum $a_{W}$ for DON production $[32,33]$.

2.3.2. Inoculation and Incubation. Rehydrated wheat grains were placed in sterile $9 \mathrm{~cm}$ Petri dishes to form a monolayer of grains $(20 \mathrm{~g})$. Then a $4 \mathrm{~mm}$ diameter agar disk was taken from the margin of a 7-day-old growing colony of each isolate on potato dextrose agar (PDA) at $25^{\circ} \mathrm{C}$ and transferred to the centre of each plate. Petri plates were placed in closed plastic containers together with beakers of glycerol-water solution at $0.995 a_{W}$ in order to maintain the correct equilibrium of relative humidity inside the boxes. Containers were incubated at $28^{\circ} \mathrm{C}$ during a maximum period of twelve days.

2.3.3. Extraction of Deoxynivalenol. DON analyses were carried out following the methodology proposed by Cooney et al. [34] with some modifications. After 3, 5, 8, and 10 days of incubation, two replicates per treatment were destructively sampled, dried at $60^{\circ} \mathrm{C}$ for $24 \mathrm{~h}$, and stored at $-20^{\circ} \mathrm{C}$. A $15 \mathrm{~g}$ portion of a finely ground wheat sample was added to an Erlenmeyer flask along with $40 \mathrm{~mL}$ mixture of acetonitrile: methanol $(14: 1)$. The mixture was shaken $(150 \mathrm{rpm})$ for one hour and filtered through Whatman $\mathrm{N}^{\circ} 1$ filter to remove particulate matter. An aliquot of two milliliters of each portion was taken and added to a cleanup cartridge, which were prepared with a $3 \mathrm{~mL}$ disposable syringe. Packing consisted of a filter paper disk, followed by a layer of glass wool and $500 \mathrm{mg}$ of mixture of alumina: carbon $(20: 1)$. DON was eluted from the column with $500 \mu \mathrm{L}$ of acetonitrile: methanol: water $(80: 5: 15)$ (HPLC grade) at a flow rate of 1 drop per second and the combined elude was evaporated with nitrogen at $50^{\circ} \mathrm{C}$.

2.3.4. Quantification of Deoxynivalenol. The evaporated extract was resuspended in $500 \mu \mathrm{L}$ of methanol : water $(95: 5)$ and injected into the high performance liquid chromatograph (HPLC). Detection and quantification of DON from the dried extracts were performed by HPLC (Waters 717 plus
Autosampler) with UV detector $(220 \mathrm{~nm})$. The chromatographic separations were carried out on a $\mathrm{C}_{18}$ reverse phase column $(150 \times 4.6 \mathrm{~mm}, 5 \mu \mathrm{m}$ particle size, waters $)$. The mobile phase used a mixture of water : methanol $(88: 12)$. The flow of the mobile phase was $1.5 \mathrm{~mL} \mathrm{~min}^{-1}$. The solutions were prepared by dissolving DON standard (Sigma Aldrich Co., St. Louis, MO, USA, purity > 99\%) with methanol. Quantification was performed by measuring the peaks and extrapolation to a calibration curve obtained using standard solutions using the Empower software.

2.4. Statistical Analysis. Data were analyzed statistically using PROC GLM in SAS program (SAS Institute Inc., Cary, NC, USA) through an ANOVA. Means were compared by Fishers LSD test to determine the significant difference between the different treatments assayed.

\section{Results}

Eleven F. graminearum isolates obtained from wheat spikes from Pampas region, Argentina, were cultured in different media for several days, and samples were taken daily from supernatants of the respective culture media, and the enzymatic activities were assessed, to obtain the moment of the highest enzyme activity.

\subsection{Enzymatic Analysis}

Polygalacturonase Activity. Enzyme activity of PG against polygalacturonic acid was maximal between the $2 \mathrm{nd}$ and $3 \mathrm{rd}$ day of incubation for all studied isolates (which ranged from 9 to $130 \mathrm{U} / \mathrm{mL}$ ); then the activity decreased gradually with time, until it remained at constant levels on the end of culture time. The maximum value of PG activity was detected in the isolate number 1 , reaching a maximum of $130 \mathrm{U} / \mathrm{mL}$ at $2 \mathrm{nd}$ incubation day. Three of the isolates showed very low values of PG activity in relation to the other ones $(9,10$, and 11$)$, while the other isolates produced high polygalacturonase activity, with differences among them, as shown in Figure 1.

Proteolytic Activity. The proteolytic activity of the isolates, showed a pattern similar to the PG activity, reaching maximum values between $2 \mathrm{nd}$ and 3rd day of incubation (which ranged from 1 to $11 \mathrm{U} / \mathrm{mL}$ ). Of the 11 isolates studied, only three of them showed low activity $(8,9$, and 11$)$ in relation to the other ones. The highest activity value was detected in isolate number 1 at the 2 nd day of incubation $(11 \mathrm{U} / \mathrm{mL})$, coinciding with the one observed for PG activity (Figure 2). From the three isolates with low proteolytic activity, two of them showed also low PG activity (9 and 11).

Lipase Activity. As regards the lipase activity produced during the incubation time, two isolates were not capable of producing this enzymatic activity (5 and 9 ). The first isolate showed low activity for the other tested enzymes. For the remaining isolates, the activity increased gradually reaching maximum values between the 12th and 14th incubation day (which ranged from 3 to $15 \mathrm{U} / \mathrm{mL}$ ), then the activity gradually decreased. The maximum value for lipase activity was also detected in isolate number $1(15 \mathrm{U} / \mathrm{mL})$ on the 12 th incubation 


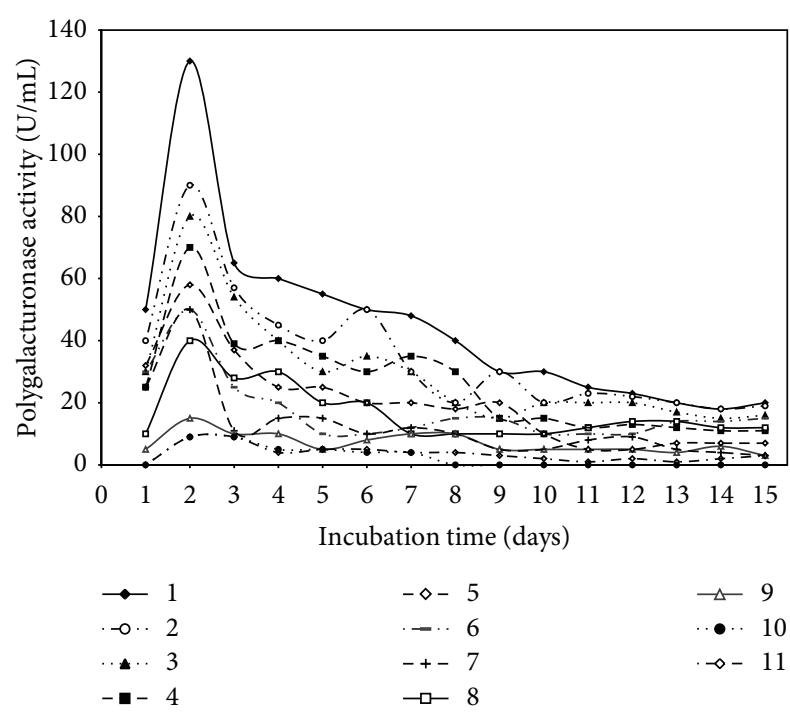

FIGURE 1: Polygalacturonase activity produced by F. graminearum isolates over an incubation maximum period of 15 days. Values are means of 8 replicates.

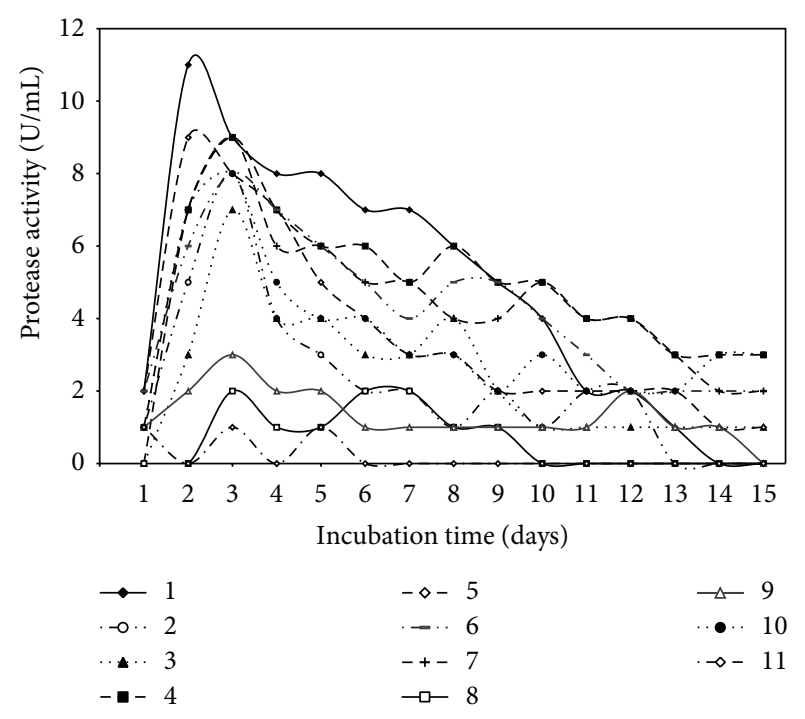

FIGURE 2: Protease activity produced by F. graminearum isolates over an incubation maximum period of 15 days. Values are means of 8 replicates.

day. Comparatively, the isolates number $4,10,11$, and 8 had low to medium activity, and the rest of them had medium to high activity (Figure 3).

3.2. Determination of Deoxynivalenol. No DON was found, as expected, at early stage of infection (3 days) for any of the analyzed isolates. Then, two of them ( 1 and 2$)$ were able to produce higher concentrations as incubation time increased reaching maximum DON levels at 10 days of incubation, with no statistically significant difference ( 50.7 and $52.3 \mu \mathrm{g} / \mathrm{g}$, resp.), while DON production by the isolates 4,9 , and 10 was only detected at 10 days of incubation $(42.4,31.5$, and

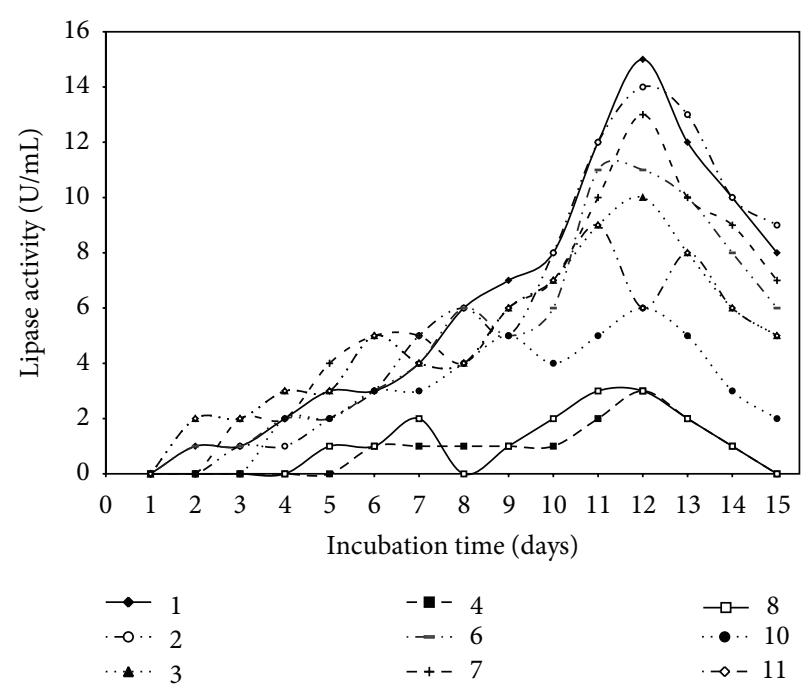

FIGURE 3: Lipase activity produced by F. graminearum isolates over an incubation maximum period of 15 days. Values are means of 8 replicates.

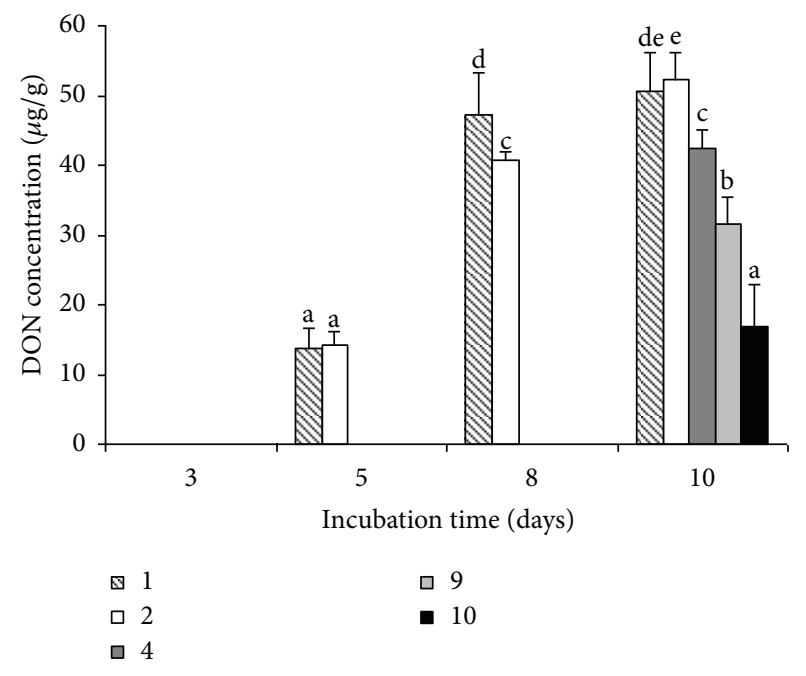

Figure 4: Mean DON production ( $\mu \mathrm{g} / \mathrm{g})$ by F. graminearum isolates on irradiated wheat grain at $0.995 a_{W}$ level and $30^{\circ} \mathrm{C}$ over an incubation maximum period of 10 days. Values are means of 3 replicates. The letters in common are not significantly different according to LSD test $(P<0.0001)$.

$16.8 \mu \mathrm{g} / \mathrm{g}$ resp.). The remaining isolates did not produce DON during the evaluated incubation period (Figure 4). The statistical analysis showed that both the isolates and the days of incubation influence significantly DON production $(P<$ 0.0001).

3.3. Statistical Analysis. The analysis of variance of the effect of single factor (isolates and days) showed that all factors alone and all interactions were statistically significant $(P<$ $0.0001)$ in relation to the corresponding enzymatic activity (Table 1). 
TABle 1: Analysis of variance of days (d) and different isolates $(i)$ and their interactions on PGase, protease, and lipase activity, respectively.

\begin{tabular}{|c|c|c|c|c|c|c|c|c|c|c|}
\hline \multirow{2}{*}{ Variation source } & \multirow{2}{*}{ df } & \multicolumn{2}{|c|}{ PGase } & \multicolumn{2}{|c|}{ Protease } & \multicolumn{2}{|c|}{ Lipase } & \multirow{2}{*}{$\mathrm{df}$} & \multicolumn{2}{|c|}{$\mathrm{DON}$} \\
\hline & & MS & $F$ & MS & F & MS & $F$ & & MS & $F$ \\
\hline$i$ & 10 & 23264.22 & $174.31^{*}$ & 332.57 & $872.37^{*}$ & 767.70 & $1923.79^{*}$ & 3 & 1479.13 & $190.63^{*}$ \\
\hline$d$ & 14 & 12725.49 & $95.35^{*}$ & 238.63 & $625.97^{*}$ & 389.02 & $974.87^{*}$ & 4 & 4414.26 & $568.92^{*}$ \\
\hline$i \times d$ & 140 & 824.42 & $6.18^{*}$ & 11.90 & $31.22^{*}$ & 34.38 & $86.15^{*}$ & 12 & 371.73 & $47.91^{*}$ \\
\hline$R^{2}$ & & \multicolumn{2}{|c|}{0.77} & \multicolumn{2}{|c|}{0.95} & \multicolumn{2}{|c|}{0.97} & & \multicolumn{2}{|c|}{0.99} \\
\hline
\end{tabular}

df: degrees of freedom.

MS: mean square.

$F$ : F-Snedecor.

${ }^{*}$ Significant $P<0.0001$.

\section{Discussion}

Since the substantial economic losses in cereal result from F. graminearum infection, and considering the variability among isolates of the species, their earlier characterization is useful as the initial measure for further research.

FHB infection consists of two phases, initial infection and spread of disease symptoms within a wheat spike. In the first 48 hours the initial biotrophic phase develops, with growth of intercellular fungal hyphae in the host, being the stage where enzymes play a decisive role. Then, the necrotrophic phase is developed with intracellular hyphae growth in the host and beginning of mycotoxin production [35]. Even though, the initial infection or establishment of infection depends on the inoculum level, environmental conditions, and the state of development of the host; it is appropriate to consider also the aggressiveness variation among isolates as Malbrán et al. [3] suggested.

The infection process of Fusarium spp. on wheat spike has been extensively studied by observing degradation of host cell wall components and localization of trichothecene toxins by means of different methodologies such as enzyme-gold and immunogold labelling followed by electron microscopy $[7,8$, $12,36,37]$.

The present study provides tools as selection criteria of F. graminearum isolates for further investigation, as the evaluation of behavior of wheat genotypes to FHB and the detection of new sources of resistance among different wheat lines and cultivars. Therefore it is necessary to select one $F$. graminearum isolate through feasible procedures and not to get too extended in time focusing on performing that aim.

Since the aggressiveness is determined by various factors and variables, different criteria can be used to estimate the infectivity of the inoculum obtained from isolates. The criteria used are estimates, not conclusive, which could be considered as complementary data. For this reason, the detection and analysis of some enzymatic activities were selected, according to the relevance of their function in the infective process. The pectinases are crucial to start the infection process, allowing the action of other enzymes. On the other hand, the loss of grain quality for their marketing focuses on the action of proteases on storage proteins and mycotoxin content. Moreover, although lipases have been scarcely studied, they would act to a certain extenst in the prior degradation of the external cuticle. Since this paper analyzes simultaneously both, the in vitro enzymatic activity and the DON production as estimative of isolates aggressiveness, the criterion proposed for characterization and selection of isolates would result in a novel approach.

In this report, the PG and proteolytic enzymatic activities were detected for all isolates in an early stage of the incubation time. Regarding the lipase activity, only in two isolates the activity was not detected, reaching in the other isolates the maximum value at the higher incubation periods. In general, production patterns obtained during the incubation time were similar, with a different magnitude.

In fact, F. graminearum isolates produced in vitro enzymes, which is a good indication that it may also occur under natural conditions. Jenczmionka and Schäfer [9] determined by using modified genotypes that $F$. graminearum can produce various cell wall degrading enzymes in vitro and analyzed their regulation, suggesting that the initial infection depends of the secretion of these enzymes. In agreement with those authors, the analyzed isolates in the present study produce enzymes considered necessary for infect process in wheat. Schwarz et al. [38] also determined from assay in greenhouse that both CWDE as the proteases are involved in the colonization of the grain and consequent reduction of their quality.

Our results showed that at least a minimum of five days of incubation were required for some isolates (and even more incubation time for the others) to produce detectable DON concentrations, which would infer its relation with the progress of the disease in wheat, more than with the early stages of infection by F. graminearum as Bai et al. [35] reported.

Based on antecedents, it is noted that the role of mycotoxins in plant disease has been controversial. In FHB disease, there are diverse interactions between wheat genotypes and pathogen isolates, which makes it difficult to understand completely the role of DON in the pathogenesis. The different mechanisms of resistance of wheat would be in relation to the difficulty in interpreting DON concentrations detected in the infection [35]. Kang and Buchenauer [7] observed histologically by immuno-gold localization of DON in wheat spikes that its concentration at initial stage was probably too low to interfere with the initial infection process.

Jansen et al. [13] using modified wheat genotypes and microscopic techniques analyzed the temporal patterns of infection by F. graminearum and determined that DON is not 
a factor involved in initial infection, suggesting the critical role of enzymes in this phase.

Although the results obtained determined that numerous isolates had high enzymatic activities related to infection process, what is remarkable is the isolate number 1 for its production, which had also high toxicogenic capacity, so it could be selected for further research on the evaluation of the disease on different wheat genotypes.

\section{Conclusion}

Since FHB is one of the most devastating diseases on wheat that alter the yield and quality of the grain worldwide, an earlier characterization of Fusarium graminearum isolates regarding to aggressiveness components such as enzymes and mycotoxins production would be useful as selection criteria for further investigation tending to help disease control. This would be the first study that reports simultaneously both, the in vitro enzymatic activity and the DON production as estimative of isolates aggressiveness.

\section{Conflict of Interests}

There is not any kind of conflict of interests with any trademark mentioned in this paper, competitive interest, or secondary interest that could have influenced the research. This declaration is carried out by all the authors of the work presented.

\section{Acknowlegments}

The authors thank Consejo Nacional de Investigaciones Científicas y Tecnológicas (Grant PIP 1422) and FONCYT PICT 2011-0851 for financial support and acknowledge the technical assistance of Bernardina Catalina López and Esteban Manuel González.

\section{References}

[1] F. A. Lazzari, "Control integrado de plagas, manejo de hongos e insectos," Granos y Post-Cosecha Latinoamericana, vol. 6, no. 23, 2000.

[2] S. R. Pirgozliev, S. G. Edwards, M. C. Hare, and P. Jenkinson, "Strategies for the control of Fusarium head blight in cereals," European Journal of Plant Pathology, vol. 109, no. 7, pp. 731-742, 2003.

[3] I. Malbrán, C. A. Mourelos, J. R. Girotti, M. B. Aulicino, P. A. Balatti, and G. A. Lori, "Aggressiveness variation of Fusarium graminearum isolates from Argentina following point inoculation of field grown wheat spikes," Crop Protection, vol. 42, pp. 234-243, 2012.

[4] Á. Mesterházy, T. Bartók, C. G. Mirocha, and R. Komoróczy, "Nature of wheat resistance to Fusarium head blight and the role of deoxynivalenol for breeding," Plant Breeding, vol. 118, no. 2, pp. 97-110, 1999.

[5] G. E. Kikot, R. A. Hours, and T. M. Alconada, "Contribution of cell wall degrading enzymes to pathogenesis of Fusarium graminearum: a review," Journal of Basic Microbiology, vol. 49, no. 3, pp. 231-241, 2009.
[6] G. E. Kikot, R. A. Hours, and T. M. Alconada, "Extracellular enzymes of Fusarium graminearum isolates," Brazilian Archives of Biology and Technology, vol. 53, no. 4, pp. 779-783, 2010.

[7] Z. Kang and H. Buchenauer, "Ultrastructural and cytochemical studies on cellulose, xylan and pectin degradation in wheat spikes infected by Fusarium culmorum," Journal of Phytopathology, vol. 148, no. 5, pp. 263-275, 2000.

[8] Z. Kang and H. Buchenauer, "Cytology and ultrastructure of the infection of wheat spikes by Fusarium culmorum," Mycological Research, vol. 104, no. 9, pp. 1083-1093, 2000.

[9] N. J. Jenczmionka and W. Schäfer, "The Gpmk1 MAP kinase of Fusarium graminearum regulates the induction of specific secreted enzymes," Current Genetics, vol. 47, no. 1, pp. 29-36, 2005.

[10] J. M. Wagacha and J. W. Muthomi, "Fusarium culmorum: infection process, mechanisms of mycotoxin production and their role in pathogenesis in wheat," Crop Protection, vol. 26, no. 7, pp. 877-885, 2007.

[11] H. Jackowiak, D. Packa, M. Wiwart, J. Perkowski, M. Busko, and A. Borusiewicz, "Scanning electron microscopy of mature wheat kernels infected with Fusarium culmorum," Journal of Applied Genetic, vol. 43, pp. 167-176, 2002.

[12] W. M. Wanjiru, K. Zhensheng, and H. Buchenauer, "Importance of cell wall degrading enzymes produced by Fusarium graminearum during infection of wheat heads," European Journal of Plant Pathology, vol. 108, no. 8, pp. 803-810, 2002.

[13] C. Jansen, D. von Wettstein, W. Schäfer, K. Kogel, A. Felk, and F. J. Maier, "Infection pattern in barley and wheat spikes inoculated with wild-type and trichodiene synthase gene disrupted Fusarium graminearum," Proceedings of the National Academy of Sciences of the United States of America, vol. 102, no. 46, pp. 16892-16897, 2005.

[14] V. Phalip, F. Delalande, C. Carapito et al., "Diversity of the exoproteome of Fusarium graminearum grown on plant cell wall," Current Genetics, vol. 48, no. 6, pp. 366-379, 2005.

[15] A. T. Have, W. Mulder, J. Visser, and J. A. L. van kan, “The endopolygalacturonase gene Bcpg1 is required to full virulence of Botrytis cinerea," Molecular Plant-Microbe Interactions, vol.11, no. 10, pp. 1009-1016, 1998.

[16] F. I. García-Maceira, A. Di Pietro, M. D. Huertas-González, M. C. Ruiz-Roldán, and M. I. G. Roncero, "Molecular characterization of an endopolygalacturonase from Fusarium oxysporum expressed during early stages of infection," Applied and Environmental Microbiology, vol. 67, no. 5, pp. 2191-2196, 2001.

[17] O. Valette-Collet, A. Cimerman, P. Reignault, C. Levis, and M. Boccara, "Disruption of Botrytis cinerea pectin methylesterase gene Bcpmel reduces virulence on several host plants," Molecular Plant-Microbe Interactions, vol. 16, no. 4, pp. 360-367, 2003.

[18] M. I. G. Roncero, C. Hera, M. Ruiz-Rubio et al., "Fusarium as a model for studying virulence in soilborne plant pathogens," Physiological and Molecular Plant Pathology, vol. 62, no. 2, pp. 87-98, 2003.

[19] M. J. Nightingale, B. A. Marchylo, R. M. Clear, J. E. Dexter, and K. R. Preston, "Fusarium head blight: effect of fungal proteases on wheat storage proteins," Cereal Chemistry, vol. 76, no. 1, pp. 150-158, 1999.

[20] A. J. Barneix, "Physiology and biochemistry of source-regulated protein accumulation in the wheat grain," Journal of Plant Physiology, vol. 164, no. 5, pp. 581-590, 2007.

[21] B. Brzozowski, K. Dawidziuk, and W. Bednarski, "Gliadin degradation by proteases of Fusarium genus fungi in different in 
vivo and in vitro conditions," Polish Journal of Natural Sciences, vol. 23, pp. 188-206, 2008.

[22] J. Feng, G. Liu, G. Selvaraj, G. R. Hughes, and Y. Wei, "A secreted lipase encoded by LIP1 is necessary for efficient use of saturated triglyceride lipids in Fusarium graminearum," Microbiology, vol. 151, no. 12, pp. 3911-3921, 2005.

[23] C. Pritsch, G. J. Muehlbauer, W. R. Bushnell, D. A. Somers, and C. P. Vance, "Fungal development and induction of defense response genes during early infection of wheat spikes by Fusarium graminearum," Molecular Plant-Microbe Interactions, vol. 13, no. 2, pp. 159-169, 2000.

[24] R. H. Proctor, T. M. Hohn, and S. P. McCormick, "Reduced virulence of Gibberella zeae caused by disruption of a trichothecene toxin biosynthetic gene," Molecular Plant-Microbe Interactions, vol. 8, no. 4, pp. 593-601, 1995.

[25] S. D. Harris, "Morphogenesis in germinating Fusarium graminearum macroconidia," Mycologia, vol. 97, no. 4, pp. 880-887, 2005.

[26] P. B. Schwarz, R. D. Horsley, B. J. Steffenson, B. Salas, and J. M. Barr, "Quality risks associated with the utilization of Fusarium head blight infected malting barley," Journal of the American Society of Brewing Chemists, vol. 64, no. 1, pp. 1-7, 2006.

[27] M. J. Martínez, M. T. Alconada, F. Guillén, C. Vázquez, and F. Reyes, "Pectic activities from Fusarium oxysporum f. sp. melonis: purification and characterization of an exopolygalacturonase," FEMS Microbiology Letters, vol. 81, no. 2, pp. 145-150, 1991.

[28] M. Somogyi, "Notes on sugar determination," The Journal of Biological Chemistry, vol. 195, no. 1, pp. 19-23, 1952.

[29] M. M. Bradford, "A rapid and sensitive method for the quantitation of microgram quantities of protein utilizing the principle of protein dye binding," Analytical Biochemistry, vol. 72, no. 1-2, pp. 248-254, 1976.

[30] M. Hellweg, Molecular biological and biochemical studies of proteolytic enzymes of the cereal pathogen Fusarium graminearum [Inaugural Dissertation der Westfälischen Wilhelms], Universität Münster, 2003.

[31] C. Sequeiros, L. M. I. López, N. O. Caffini, and C. L. Natalucci, "Proteolytic activity in some Patagonian plants from Argentina," Fitoterapia, vol. 74, no. 6, pp. 570-577, 2003.

[32] M. L. Ramirez, S. Chulze, and N. Magan, "Temperature and water activity effects on growth and temporal deoxynivalenol production by two Argentinean strains of Fusarium graminearum on irradiated wheat grain," International Journal of Food Microbiology, vol. 106, no. 3, pp. 291-296, 2006.

[33] M. Schmidt-Heydt, R. Parra, R. Geisen, and N. Magan, "Modelling the relationship between environmental factors, transcriptional genes and deoxynivalenol mycotoxin production by strains of two Fusarium species," Journal of the Royal Society Interface, vol. 8, no. 54, pp. 117-126, 2011.

[34] J. M. Cooney, D. R. Lauren, and M. E. Di Menna, "Impact of competitive fungi on trichothecene production by Fusarium graminearum," Journal of Agricultural and Food Chemistry, vol. 49, no. 1, pp. 522-526, 2001.

[35] G. H. Bai, A. E. Desjardins, and R. D. Plattner, "Deoxynivalenolnonproducing Fusarium graminearum causes initial infection, but does not cause disease spread in wheat spikes," Mycopathologia, vol. 153, no. 2, pp. 91-98, 2002.

[36] Z. Kang, H. Buchenauer, L. Huang, Q. Han, and H. Zhang, "Cytological and immunocytochemical studies on responses of wheat spikes of the resistant Chinese cv. Sumai 3 and the susceptible cv. Xiaoyan 22 to infection by Fusarium graminearum,"
European Journal of Plant Pathology, vol. 120, no. 4, pp. 383-396, 2008.

[37] Z. Kang, I. Zingen-Sell, and H. Buchenauer, "Infection of wheat spikes by Fusarium avenaceum and alterations of cell wall components in the infected tissue," European Journal of Plant Pathology, vol. 111, no. 1, pp. 19-28, 2005.

[38] P. B. Schwarz, B. L. Jones, and B. J. Steffenson, "Enzymes associated with Fusarium infection of barley," Journal of the American Society of Brewing Chemists, vol. 60, no. 3, pp. 130$134,2002$. 

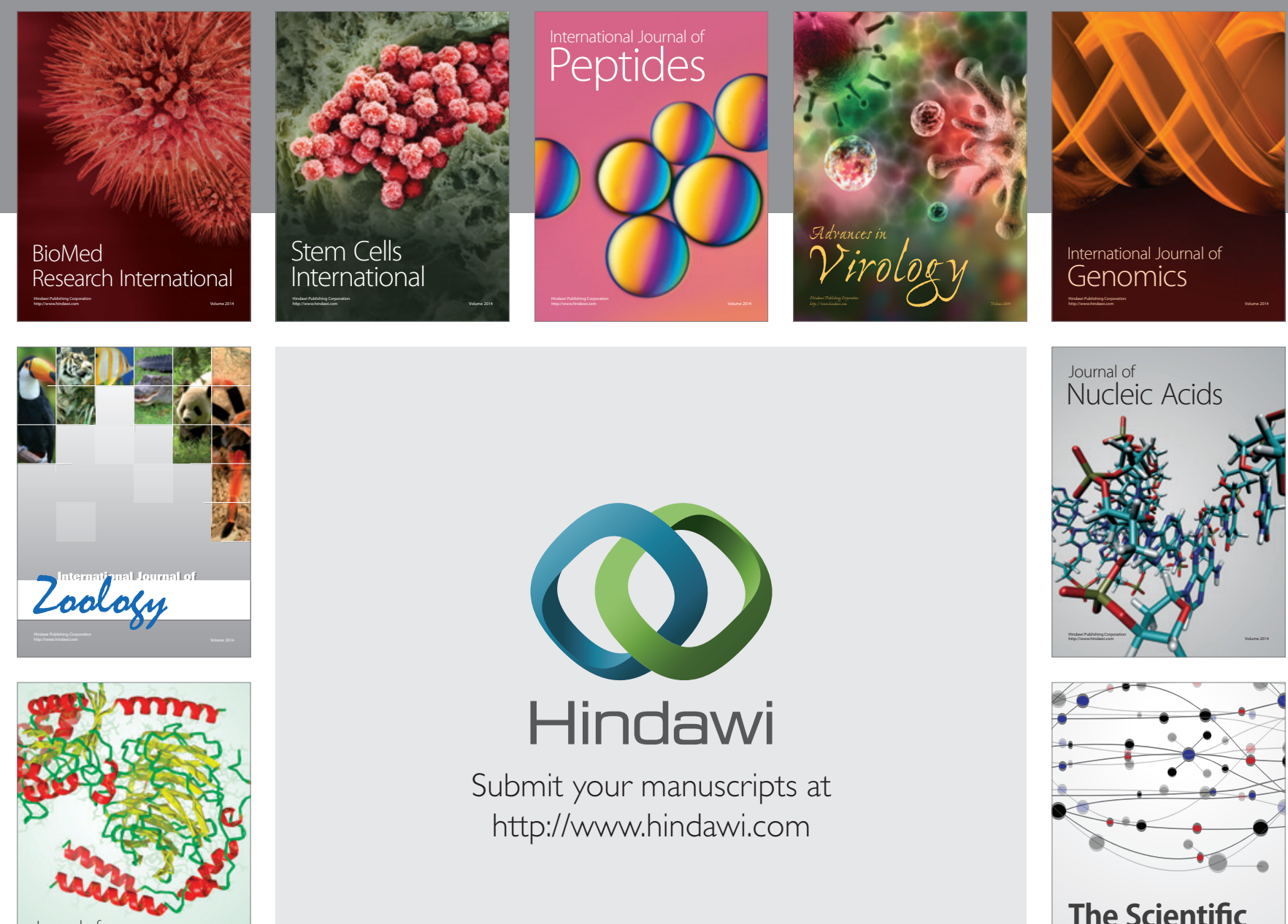

Submit your manuscripts at

http://www.hindawi.com

Journal of
Signal Transduction
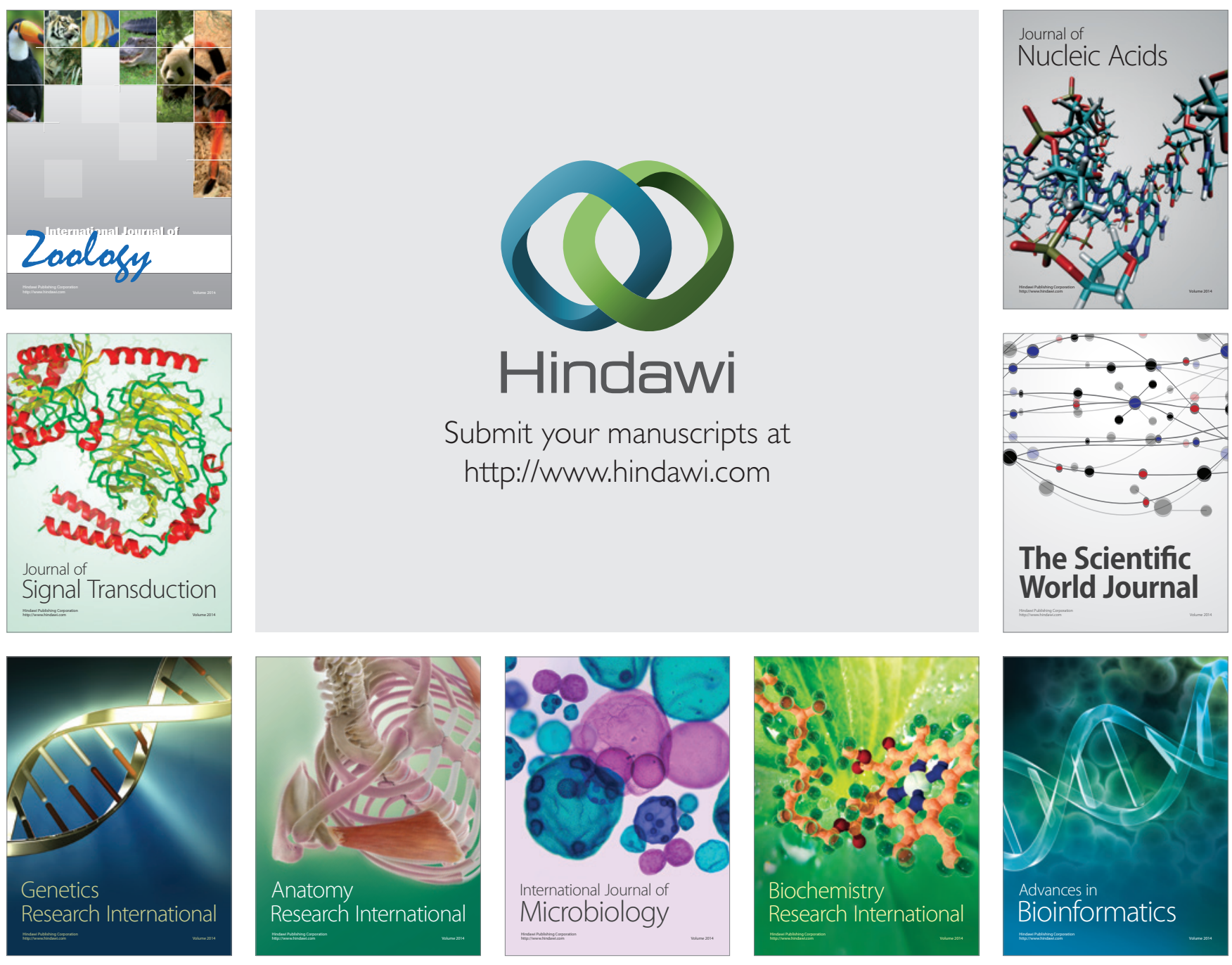

The Scientific World Journal
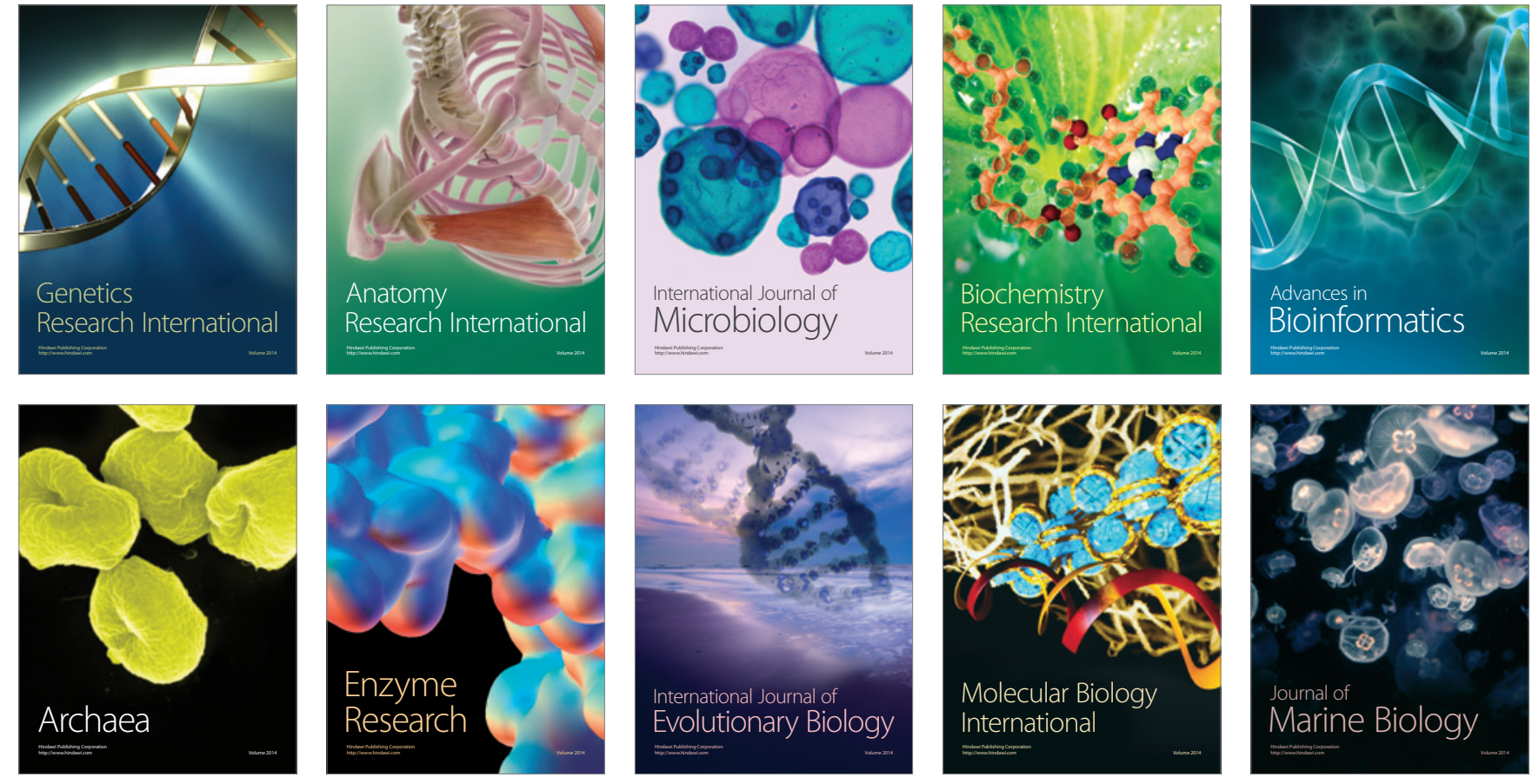